\title{
Shareholder Types, Corporate Governance and Firm Performance: An Anecdote from Indian Corporate Sector
}

\author{
Dr Namita Rajput \\ Associate Prof. in Commerce \\ Sri Aurobindo College, USMS, GGS \\ University of Delhi, India \\ E-mail: namitarajput27@gmail.com \\ Ms Bharti ( Corresponding Author) \\ Assistant Professor in Management \\ Indraprastha University, India \\ E-mail: bharti.1119@gmail.com
}

Received: August 5, 2014 Accepted: Nov.11, 2014 Published: June 1, 2015

doi:10.5296/ajfa.v7i1.6070 URL: http://dx.doi.org/10.5296/ajfa.v7i1.6070

\begin{abstract}
The issues regarding corporate governance have received major attention owing to their apparent importance for the economic health of companies especially after plethora of corporate scams and debacles in the recent times. High ethical values can reduce costs to achieve a high corporate governance standard and make it more sustainable. Improving corporate governance is an issue of critical importance to India today and for future developments. The Indian government has realized that good corporate governance is necessary to improve corporate competitiveness and to attract foreign investors. It is believed that with better corporate governance, listed firms can reduce agency costs, become more competitive in global markets, and fulfill their social responsibilities. There are no conclusive evidences so far in the literature in proving the linkages between shareholder types and firm performance, hence the present study will add and address the glaring knowledge gap in Indian literature. The typical shareholder types among listed companies in India are
\end{abstract}


institutions, government, managers, foreigners and diverse shareholders. Using panel regression, the relationships between shareholder types and financial performance as measured by Tobin's Q, ROA, ROE were tested taking a sample of BSE100 companies excluding banking and insurance companies. The analysis of the result shows significant positive influence of foreign institutional investors and family ownership on ROE whereas government and retail shareholder affect ROE negatively. Also, the corporate governance index has a significantly negative impact on ROE. However, the relationship of CGI with ROA and Tobin's Q was not found to be significant.

Keywords: Corporate Governance, Shareholder types; Firm Performance, Agency Cost, Corporate Governance Index 


\section{Introduction}

In some ways Corporate Governance is not a new concept; responsibility in the handling of money and conduct of business and commerce has always been important. In the last century or so, with the increasing complexity and power of corporations, it has come to the fore emphatically. A decisive beginning was made in this direction when after the introduction of liberal-market reforms, the Indian Corporate Sector, led by CII, drew up a voluntary code of Corporate Governance (CG). Further developments from there vacillated between making CG voluntary or mandatory. By the year 2000, the same had been incorporated as a necessity in the clause 49 of the listing agreement administered by the market regulator SEBI as per the recommendations of The Birla Committee that specifically placed an emphasis on independent directors. The Committee also recognized the importance of audit committees and made many specific recommendations regarding the function and constitution of board audit committees. It was followed by the Naresh Chandra Committee report with major stress on independent oversight of board and audit, and improvements in disclosures (financial as well as non-financial). In the subsequent years, two more committees were constituted under the leadership of Mr Narayan Murthy and Mr J J Irani, with the explicit aim of bringing in best practices from around the world to create a well regulated environment that promotes entrepreneurship. In 2009, the Satyam fiasco shook the Indian industry, bringing home the point that proper governance is indispensable to further growth and development. Since then efforts to create a framework have gained urgency. The Ministry of Corporate Affairs (MCA) came out with guidelines in 2009. In its present form, Clause 49, called 'Corporate Governance', contains eight sections dealing with the Board of Directors, Audit Committee, Remuneration of Directors, Board Procedure, Management, Shareholders, Report on Corporate Governance, and Compliance. Firms that do not comply with Clause 49 can be de-listed and face financial penalties. Now, the Companies Act, 2013 which has been enacted recently, has further strengthened the CG norms.

There are four major sources of forces directly shaping a company's corporate governance: (1) individual ethics and corporate cultures, (2) internal ownership/control and incentive mechanisms, (3) market and external monitoring mechanisms, and (4) laws and regulations and their enforcement. Clearly, corporate governance is also affected by a firm's institutional environments and its own attributes. High ethical values can reduce costs to achieve a high corporate governance standard and make it more sustainable. This relies on companies setting ethical guidelines and good communication channels with all levels of staff so that the same corporate values are attained by every member of the organization. Corporate culture does begin with the personal values of the top management. Unfortunately, one fundamental concern in India is the low ethical standard in business and the lack of proper corporate culture. Improving corporate governance is an issue of critical importance to India today and for future developments. The Indian government has realized that good corporate governance is necessary to improve corporate competitiveness and to attract international capital. It is believed that with better corporate governance, listed firms can reduce agency costs, become more competitive in global markets, and fulfill their social responsibilities.

Empirical evidence presented in this study underlines the importance of ownership structure 
in terms of the types of shareholders and the Corporate Governance Index on financial performance of the company. Different financial performance measures are used by researchers and the indicators include profitability, efficiency, leverage and liquidity. The selection of performance measures depends on the research objectives. Three measures of performance, as supported in the finance and accounting literature were chosen for the purpose of analysis, namely ROA, ROE and Tobin's Q as proxy for firm performance.

Our research studies the effect of twelve variables on firm performance as measured by ROE. These independent variables are Retail Shareholding, Institutional Shareholders, Government ownership, Family shareholding, FII Shareholding, Corporate Shareholding and Corporate Governance Index. Also, control variables such as firm's size, proxy by total assets, firm's age since its inception and leverage proxy by debt equity ratio are considered as exogenous variables. We have also included advertising expenses and board size of the sample firms.

Table 1. Variables Studied

\begin{tabular}{|c|c|c|}
\hline Variables Used & Definition & $\begin{array}{l}\text { Symbol } \\
\text { Used }\end{array}$ \\
\hline Return on Equity & Net profit as a percentage of shareholder's equity & $\mathrm{ROE}$ \\
\hline Return on Assets & Net profit as a percentage of total assets & $\mathrm{ROA}$ \\
\hline Tobin's Q & $\begin{array}{l}\text { Market value of equity plus book value of debt and } \\
\text { preference share capital divided by total assets }\end{array}$ & Tobin's Q \\
\hline Retail Shareholding & Percentage of shares held by individuals & $\mathrm{RSH}$ \\
\hline $\begin{array}{l}\text { Institutional } \\
\text { Shareholding }\end{array}$ & Percentage of shares held by institutions & IISH \\
\hline $\begin{array}{l}\text { Government } \\
\text { Shareholding }\end{array}$ & Percentage of shares held by Government & GSH \\
\hline Family Shareholding & Percentage of shares held by family & FSH \\
\hline FII Shareholding & Percentage of shares held by foreign institutional investors & FIISH \\
\hline Corporate Shareholding & $\begin{array}{l}\text { Percentage of shares held by corporate bodies, excluding } \\
\text { those already covered }\end{array}$ & $\mathrm{CSH}$ \\
\hline Size & Firm size in terms of total assets owned & $\mathrm{S}$ \\
\hline Advertising Expenses & $\begin{array}{l}\text { Includes sum of advertising, marketing and distribution } \\
\text { expenses }\end{array}$ & ADVT \\
\hline $\begin{array}{l}\text { Corporate Governance } \\
\text { Index }\end{array}$ & $\begin{array}{l}\text { includes the corporate governance parameters like Duality, } \\
\text { number of directors ,proportion of Non-executive directors, } \\
\text { proportion of independent directors, number of board } \\
\text { meetings held, average attendance of audit committee } \\
\text { meetings, average attendance of board meeting, number of } \\
\text { audit committee meetings, number of remuneration } \\
\text { meetings ,number of nomination committee meetings, } \\
\text { proportion of independent directors in nomination } \\
\text { committee, profile of directors, minutes of different } \\
\text { meetings, whistle blowing policy, related party disclosure }\end{array}$ & CGI \\
\hline
\end{tabular}




\begin{tabular}{|l|l|l|}
\hline Board Size & Number of directors on board & BS \\
\hline Age & $\begin{array}{l}\text { Number of years between observation year and year of } \\
\text { incorporation }\end{array}$ & AGE \\
\hline $\begin{array}{l}\text { Debt Equity Ratio } \\
\text { (Leverage) }\end{array}$ & Ratio of long term debt to equity & DEBT \\
\hline
\end{tabular}

To achieve the objective of the study, the paper is divided into following sections, Section I ,i.e. the present section gives the insights of corporate governance and its various parameters, followed by Section II which gives a brief review of literature. Section III presents research objectives and hypothesis followed by Section IV which deals with data and methodological issues. Section V entails the analysis and interpretation of empirical results which are divided into two parts, 5.1, gives the relationship between shareholder types and ROE and 5.2 analyses the relationship between CGI and financial performance. It is followed by the summary, conclusion and implications of the research contained in Section VI followed by references.

\section{Review of Literature}

The following section gives the brief snapshot of review of literature done in India and across the globe. The connection between ownership structure and performance has been the subject of an important and ongoing debate in the corporate finance literature. The debate goes back to the Berle and Means (1932) thesis, which suggests that an inverse correlation should be observed between the diffuseness of shareholdings and firm performance. Their view has been challenged by Demsetz (1983), who argues that the ownership structure of a corporation should be thought of as an endogenous outcome of decisions that reflect the influence of shareholders and of trading on the market for shares. A burgeoning empirical research shows that share ownership and its structure can be important sources of incentives for managers, boards of directors and outside shareholders (Milgrom and Roberts, 1992). In developing economies, ownership is also heavily concentrated (Blasi and Shleifer, 1996; Claessens et al., 1996; Claessens, 1997; $\mathrm{Xu}$ and Wang, 1997; La Porta et al., 1998; Yee, 1998; Wiwattanakantang, 1999; Yeh, et al., 2001; and Joh, 2003). There is evidence of pyramiding and family control of businesses in Asian countries, particularly India (Bertrand et al., 2002). It is believed that this is a result of the ineffectiveness of the legal system in protecting property rights.

McConnell and Servaes (1990) provide evidence on the relation between the distribution of equity ownership and corporate value. For the sample cross sectional relation between Tobin's Q and equity ownership is found where the value of the firm is taken to be the function of distribution of equity ownership amongst corporate insiders, individual shareholders, block shareholders and institutional investors. in the analysis, Tobin's Q ratio is regressed against various measures of ownership to gauge their impact on the value of the firm. The results show that there is a strong evidence of a curvilinear relationship between insider ownership and Q, i.e value of Q first increases as insider ownership increases and then declines on further increase in insider ownership of equity. Block shareholders have no 
significant relationship with the value of the firm and lastly institutional investors have a significant positive influence on the firm value. Shleifer and Vishny (1997) have focused on the subject of corporate governance from the perspective of agency problem, sometimes referred to as the separation of ownership and control. The basic question of corporate governance is to find out how investors get the managers to give them back their invested money. The paper discusses the role of concentration of ownership as an approach to corporate governance and takes into account ownership by small investors and concentrated ownership; i.e. by large shareholders) which reduces agency costs and thereby improves corporate governance and firm performance. The paper also discusses the negative impact of state ownership on firm performance. Thomsen, Pedersen (1998) examine the impact of ownership structure on company economic performance in the largest companies from 12 European nations. Ownership structure is measured by the identity and share of the largest owner. Performance is measured by return on assets, market to book values and sales growth controlling for industry. Five categories of shareholders have been identified: banks, other financial companies (institutional investors), other non-financial companies, personal/family and government. The authors find evidence of a bell-shaped (first increasing and then decreasing) effect of ownership share on assets returns and market-to-book values of equity. Companies whose largest owner is a financial institution have higher market-to book values than companies in which the largest owner is a family, another company or the government. The effects on asset returns are qualitatively identical, but weaker and insignificant except for a negative effect of government ownership. In contrast, companies whose largest owner is a family or another company have significantly higher sales growth. $\mathrm{Xu}$ Xiaonian, Wang Yan (1997) investigate whether ownership structure has significant effects on the performance of publicly-listed companies in China, and in what ways if it does. These companies are typically owned by five groups of agents: the state, legal persons (domestic institutions), tradable A-share holders (mostly individuals), employees, and foreign investors. The data set includes all SHSE and SZSE listed companies for 1993, 1994 and 1995. The authors have employed three accounting ratios to measure the firm's performance, the market-to-book value ratio (MBR), ROE, and ROA. The paper concludes that the firm's performance is positively correlated with legal persons(institutional shareholders). In contrast, the fraction of equity owned by individual shareholders, has a significant negative effect on the market-to-book ratios, consequently individual shareholders have a negative relation with the firm's performance. Also the authors conclude a negative relationship between the shares owned by the state and firm performance. In the paper, the influence of individual shareholders to firm's profitability is insignificant, if not completely irrelevant. In many cases, the relationship between equity held by individual investors and firm performance is significant but negative, indicating that the market values individual private ownership downward.

Claessens, Djankov, Fan and Lang (1999) have studied the relationship between the concentration of cash flow rights and control rights and the type of block ownership on one hand and corporate valuation on the other hand in East Asian corporations for the year 1996. The analysis is based on newly-assembled data for publicly-traded corporations (including both financial institutions and non-financial institutions) in Hong Kong, Indonesia, Japan, 
Korea, Malaysia, the Philippines, Singapore, Taiwan, and Thailand. In the majority of cases, the principal shareholders are themselves corporate entities, not-for-profit foundations, or financial institutions. The paper documents the relation between ultimate ownership and market valuation, differentiating between control from cash-flow rights. It is found that higher cash-flow rights are associated with higher market valuation, but higher control rights are associated with lower market valuation, especially when cash-flow rights are low and control rights are high. This suggests expropriation of minority shareholders by controlling shareholders. The authors conclude that family control is an important factor behind the negative relation between control rights and market valuation. In contrast, no evidence of expropriation for state control and control by widely-held corporations is found. Finally, the relation between control by financial institutions and market valuation is negative. Repei, (2000) has analyzed a sample of 318 companies for 1997 - 1998 years. The sample comprises companies from all regions of Ukraine. It covers 15 sectors including fast moving service and finance. The author has formulated hypothesis to test if corporate performance varies according to the shareholder structure where the performance of the firm is taken as a function of ownership type. The corporate ownership is divided into five main categories with respect to dominant shareholder type. These are insider, home outsider, foreign outsider, individual and state. The author concludes that private ownership lead to higher performance than state one. Further, outside owners provide much better governance of assets, while private individuals are very ineffective owners due to "free-riding" problem. The state demonstrates failure in enterprise restructuring because of economically harmful political objectives. The effect of insider ownership is ambiguous. Kumar (2004) examined empirically the relationship between the ownership structure and firm performance using a panel of Indian corporate firms over 1994-2000 and found that foreign shareholding pattern did not influence the firm performance significantly. Ongore O. Vincent, K'Obonyo O. Peter, Ogutu Martin, (2011 ), analyzed forty-two firms in Kenya. The methodology adopted was calculation of Pearson's Product Moment Correlation and Logistic Regression. The results of ownership identity were analyzed based on five elements: government; foreign; institution; diverse; and manager (insider). The study found a significant positive relationship between insider ownership and firm performance. There is a significant negative relationship between government ownership and firm performance. Regarding the relationship between ownership by institutions and firm performance, the study found a significant positive relationship. Also the research concluded a significant positive relationship between diverse ownership and firm performance. Lastly the author posits a positive relationship between foreign ownership and firm performance.

To sum up, the existing literature points towards a significant and positive impact that foreign ownership brings to the firm. Also, the government as a stakeholder is of little benefit in enhancing the firm performance. Further, private individuals and retail owners are mostly ineffective in increasing the financial performance. There is a paucity of studies revealing the impact of shareholder types, corporate governance on financial performance, this study is a modest attempt in this direction. 


\section{Research Objectives and Hypothesis}

In the research, we have attempted to examine the relationship between firm performance and shareholding pattern or ownership structure. Total of 76 companies have been included from BSE 100, excluding banking and financial sector companies. Following are the objectives of the research:

1. To study effects of ownership structure (shareholding pattern) on performance of a firm in India.

2. To study the effect of corporate governance measured by Corporate Governance Index on financial performance of a firm.

\section{Data and Methodological Issues}

For our research, we have taken daily data files from BSE 100 Index. The time period of the study is from $01^{\text {st }}$ April 2007 to $31^{\text {st }}$ March 2014. The data sources were the annual reports of the companies, corporate database (PROWESS) maintained by the CMIE, the Center for Monitoring the Indian Economy, and the reports filed by companies with the BSE as part of the listing requirements. For the analysis, we took the 100 companies. We kept out all the banking and financial services companies since they are governed by the Banking Regulation Act; hence these companies were different from those governed by the Companies Act. These sample selection criteria's resulted in a final sample size of 76 companies.

\section{Key Variables}

To examine the effect of ownership structure on corporate governance and performance, the following variables were used:

\section{Measurement of Corporate Performance}

Two measures of performance, as supported in the finance and accounting literature were chosen for the purpose of analysis.

Tobin's q: Tobin and Brainard (1968) and Tobin (1969) designed a measurement of corporate performance, which is equal to the ratio of market value of equity and debt divided by the replacement costs of total assets. The notion is that replacement costs are a logical measure of the alternative-use values of the assets. Hence, unless assets used by firms are able to create at least as much value as the cost of reproducing them, the assets would be better employed elsewhere. Companies displaying Tobin's q greater than unity are considered to be using scarce resources effectively, while those with Tobin's Q less than unity as using resources poorly.

Tobin's q has been computed as [MV of common stock $+\mathrm{BV}$ of preference stock $+\mathrm{BV}$ of borrowings $+\mathrm{BV}$ of $\mathrm{CL}$ )/ $\mathrm{BV}$ of total assets as denoted by FA $+\mathrm{INV}+\mathrm{CA}$ ] with all values computed at the year end.

Return on assets (ROA). The accounting variable chosen was calculated as the ratio of net profit to assets. Total assets include value of fixed assets, investments, and current assets. 


\section{Macrothink}

Return on Equity (ROE): We measure Return on Equity Capital as the ratio of net profit to equity capital. Equity Capital is the total outstanding paid up equity capital of the firm as at the end of the accounting period. Shares issued but not paid-up or pending allotments do not form part of equity capital. This includes bonus equity shares issued, if any, by the firm in the past. ROE = Net Profit/ Equity Capital

\section{Ownership and Governance Variables}

The ownership structure and corporate governance mechanisms can influence company performance. The ownership and governance measures were analyzed as independent variables.

Ownership structure. The distribution of ownership among different categories of owners provides useful information about the corporate governance structure of a company. The shareholding has been classified according to a standard taxonomy of investors' categories and definitions as provided under Clause 35 (Appendix III) and 40A of the Listing Agreement (Appendix IV). For the cross-sectional and pooled panel regression analysis the study considers only six major groups of ownership viz., Retail shareholders, family ownership, foreign institutional investors, domestic institutional investors, government, corporate.

H1: There is a significant relationship between the ownership by $\mathrm{n}$ retail investor and return on equity.

H2: There is a significant relationship between the ownership by $\mathrm{n}$ Institutional investor and return on equity.

H3: There is a significant relationship between the ownership by Government and return on equity.

H4: There is a significant relationship between the ownership by family and return on equity.

H5: There is a significant relationship between the ownership by FII and return on equity.

H6: There is a significant relationship between the ownership by $\mathrm{n}$ corporate and return on equity

Board size: There is a view that larger boards are better for corporate performance because they have a range of expertise to help make better decisions and are harder for a powerful CEO to dominate. However, recent thinking has leaned towards smaller boards. Board size has been measured as the total number of directors on the board.

H5: There is a significant relationship between board size and return on equity.

\section{Control Variables}

In order to control for the other possible determinants of performance not captured by the ownership variables, some observed company characteristics have been included as control variables. The control variables used in the study have been selected with reference to those employed in earlier studies. 


\section{Macrothink

Age: Age of the company has an ambiguous effect a priori on company performance. It is argued that due to the effects of the learning curve and survival bias older firms are likely to be more efficient than younger ones. Thus, a better performance should be expected. However, older companies are prone to inertia, and rigidities in adaptability, which may lead to lower performance. Age has been measured as the number of years for which the company has been in existence since incorporation to the date of observation.

Size: A vast amount of literature has investigated the relation between size and performance of firms. Band (1981) and Reinganum (1981) documented that small firms have higher returns than large firms, even after adjusting for risk via the Capital Asset Pricing Model (CAPM). Lang and Stulz (1994) reported significant negative correlation between size and Tobin's Q. Firm size can be measured in different ways, using total assets as a proxy of firm size. Gilson (1997) used the natural log of total assets as a proxy of firm size. The literature also shows that alternative measures of size, based on annual sales or total asset values, do not materially affect the inferences. This has been measured by the natural logarithm of total assets of firms.

Debt-Equity: Theories on the role of debt provide us with a complementary corporate governance mechanism that monitors the management (Jensen, 1989; and Thomsen and Pedersen, 2000).

Following regression equation for our research has been formulated:

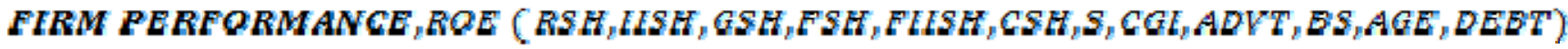

We have used pooled panel regression model. The data are usually collected over time and over the same individuals and then a regression is run over these two dimensions. The regression has been applied on the entire sample in total.

\section{Analysis And Interpretations Of Empirical Results}

\subsection{Relationship Between Shareholder Types And ROE}


Table 2. Result of Pooled Panel Regression

\begin{tabular}{|c|c|c|}
\hline \multirow{2}{*}{$\begin{array}{l}\text { Independent } \\
\text { Variables }\end{array}$} & \multicolumn{2}{|c|}{ Dependent Variables } \\
\hline & & ROE \\
\hline & Coefficients & p- value \\
\hline Intercept & 92.77196 & 0.0819 \\
\hline $\begin{array}{l}\text { Retail } \\
\text { Shareholding }\end{array}$ & -0.240335 & 0.3653 \\
\hline $\begin{array}{l}\text { Institutional } \\
\text { Investors } \\
\text { Shareholding }\end{array}$ & 0.069376 & 0.4072 \\
\hline Government & -0.105731 & 0.0171 \\
\hline $\begin{array}{l}\text { Family } \\
\text { Shareholding }\end{array}$ & 0.807634 & 0.0054 \\
\hline FII Shareholding & 0.385009 & 0.0009 \\
\hline $\begin{array}{l}\text { Corporate } \\
\text { Shareholding }\end{array}$ & -0.045606 & 0.361 \\
\hline Size & -16.8298 & 0.018 \\
\hline Log Advertising & 2.064538 & 0.0134 \\
\hline CGI & -15.82816 & 0.001 \\
\hline Board Size & 1.383278 & 0.0831 \\
\hline Age & 0.154378 & 0.2059 \\
\hline Debt-Equity & -1.9976 & 0.4354 \\
\hline R Squared & 0.20886 & \\
\hline
\end{tabular}

The table is a snapshot of the regression results on an aggregate basis. The calculations show that retail shareholding has a negative relationship with financial performance as measured by ROE, though not significant. Individual shareholders are ineffective due to "free riding" problem (Repei, 2000). The hypothesis that there is a significant relationship between the 
ownership by retail investor and return on equity is therefore rejected. The presence of institutional shareholders in a company has a positive but insignificant effect on the firm performance as seen in the results. The institutional investors help in reducing the information asymmetry associated with ownership and control. Also they have access to information that helps in decision making (Shleifer and Vishny, 1986). We therefore reject the hypothesis that institutional shareholders have a significant impact on ROE. The impact of government ownership on the firm performance is significant at $5 \%$ and is negatively related as governments are likely to pay special attention to political goals, many of which may be negatively correlated with the ROE (Pedersen and Thomsen, 1998). In fact the rationale for government ownership in welfare economics is non- profit making ( Arrow, 1969, Shephard, 1989). Accordingly we accept that there exists a significant relationship between the ownership by Government and return on equity. We accept the hypothesis that family ownership has a positive and significant impact on the financial performance of the company. Here the Incentive alignment argument is applied to explain the positive effect especially when family members also act as managers. The conflicts between principal and agent are reduced (Anderson \& Reeb (2003), Górriz \& Fumás (2005). Another widely applied argument is the long-term orientation of the family owner. While other owner types focus on profit maximization in the short term, family owners have a long term commitment to the firm and are willing to invest in the capacities that will create competitive advantages which require large investment in the beginning. The FII ownership contributes positively to ROE and the effect is significant at 5\% level. We therefore accept the hypothesis. Researchers (Aydin, Sayim and Yalama, 2007) have inference that on an average multinational corporations have performed better than the domestically owned firms. There are two main reasons. Firstly, the foreign owners are more likely to have the ability to monitor managers and give them performance based incentives and avoid behaviors that undermine the wealth creation motivation of the firm owners. The second reason is the transfer of new technology and globally tested management practices to the firm, which help in enhancing the efficiency by decreasing operating expenses and generating savings for the firm (Ongore, K'Obonyo and Ogutu, 2011).The presence of corporate ownership has a negative impact on ROE, though insignificant. However, the size (proxy by amount of assets) should have a positive effect on ROE as more assets provide the company with cushion to raise capital easily. However the factor has a negative and significant correlation with firm performance. The firm size has an ambiguous effect on the firm performance. It is argued that as the size increases, efficiency reduces as control by top managers over strategic and operational activities decreases. Advertising expenses of the firm yield positive and significant relationship with ROE at 5\%. This can be attributed to the fact that the firm gets more visibility in the market and its products are sold easily. Joshi and Hanssens, 2010 posit that advertising spending has a positive effect on the market capitalization of the firm and a negative impact on the valuation of the competitor of comparable size. The Corporate Governance Index, CGI, has a significantly negative impact on the firm performance. This is mainly because of negative and significant impact of CEO Duality, audit committee size, board meetings and presence of non-executive directors who may not have total commitment to the cause of the company because of other commitments which limits their contribution. According to Baysinger and 


\section{Ml Macrothink}

Asian Journal of Finance \& Accounting ISSN 1946-052X 2015, Vol. 7, No. 1

Heskisson, 1990, non-executive directors are limited in scope and understanding when it comes to complexities involving decision making because of their temporal position. The results show that size has a significant and positive effect in increasing the ROE at $10 \%$ significance level. The result is consistent with several studies that are in favor of a large board size as greater knowledge of the various administrators can improve performance (Coles et al., 2008 and Linck, et al., 2008). The experience of the firm proxy by age shows a positive relationship although insignificant in improving performance . Older firms gain experience based economies of scale; they enjoy superior performance (Kumar, 2004). High debt in a company leads to increased cost of capital along with risk of financial distress. This effect the ROE significantly negative at $5 \%$.

To sum up, we accept that foreign institutional investors, government and family have a significant impact on the ROE whereas corporate, retail and institutional investors have no significant effect on the financial performance as measured by ROE. Also, the control variables namely debt and size have significantly negative impact on ROE. Also CGI variable has negative impact on financial performance of the firm. R-squared value is $20.88 \%$ for ROE.

\subsection{Relationship between CGI and Financial Performance}

In this section, we have applied panel pooled regression to study the relationship between CGI and financial performance. The results are as follows:

Table 3. Result of Pooled Panel Regression of CGI with Firm Performance

\begin{tabular}{|l|l|l|l|l|l|l|}
\hline & \multicolumn{2}{|l}{ Dependent Variables } \\
\hline
\end{tabular}


Analysis of the results shows that the Corporate Governance Index (CGI) has a significantly negative impact on ROE. ROA is negatively correlated to CGI, although the relationship is insignificant at $5 \%$ significance level. CGI is negatively related to financial performance of the firm as measured by Tobin's Q, although the relationship is insignificant

$\mathrm{R}$ squared for the analysis is $5.40 \%$., $2.71 \%, 17.8 \%$

\section{Summary, Conclusions and Implications}

This paper investigates the effect of ownership structure on firm performance with sample from India. To conclude, the research questions are answered with evidence from non-financial listed companies on BSE. The nature of ownership identity in India and its effect on firm performance was analyzed using pooled panel regression. It is found that family/foundation owned firms have better financial performance and firms with government ownership show significantly negative financial performance. Foreign Institution owned firms show a positive relationship with performance. Arguments are combined to explain the results: management entrenchment argument for dispersed ownership; incentive alignment argument and long-term orientation argument for family ownership; institutional myopia argument and cost-efficiency of monitoring argument for institution ownership; information asymmetry of bureaucracy argument and dual-role argument for government ownership. The effect of owner identity on firm performance exists and varies among different types of owner, because the different owner has its own preference on firm strategic goals and varies in incentive and capability to deal with agency problems. Some of the control variables had a significant effect on the corporate performance. The control variables like leverage had a negative impact while age had a positive effect on performance. Corporate governance index had a significantly negative impact on ROE. The reason could be that the components of CGI are negatively related to the firm performance. Also, although the relationship between CGI and ROE, ROA and Tobin's Q is observed to be negative, but the impact of CGI is significant only in case of ROE.

\section{Implications of The Study}

- The findings underline that family ownership is dominant followed by institutional investors. The individuals are insignificant investor type. Since board derives its power from dominant shareholders, disciplining them is not feasible resulting in the ineffectiveness of the board. There thus exists a dual challenge of resolving conflict between not only the shareholders and management but also between dominant shareholders and minority shareholders. Shleifer and Vishny (1986) argue that large shareholders have a strong incentive to monitor managers because of their significant economic stakes.

- Sound functioning corporate governance mechanisms are of crucial importance for both local companies and foreign investors so as to tap tremendous opportunities for investment and growth which the Indian economy provides.

- There is a significant negative relationship between government ownership and firm performance. Government ownership contributes to generally poor performance of firms, due to excessive bureaucracy, nepotism, political expediency. The current study has confirmed 
this long-held position. Therefore the government should infuse private sector-like management systems and progress the divestiture program to attract more private individuals and institutions to co-own the public sector undertakings.

- In line with the above, the private players should have a stake in the projects launched by the government to make them more efficient, thereby improving the performance.

- There is a positive and significant relationship between foreign ownership and firm performance. Foreign owned companies have access to management systems whose efficacy has been tested in many contexts. The massive resource base and bail-out plans for fledgling affiliates are other factors that enhance performance of foreign owned firms.

- The debate on corporate governance pertains to board composition especially board size and independence. The introduction of independent directors is an important arrangement in monitoring the effectiveness of board of directors. It is therefore imperative to improve effectiveness of independent directors in monitoring managers especially to strengthen their independence. A major problem, however, is the limited availability of trained independent directors who are well versed with the procedures, tasks and responsibilities expected of them. One solution to this challenge is business leadership training of existing and potential independent directors in India. Hillman et al.(2000) posit to have board members with varied skills such as being insiders in the firm, business experts, support specialists for better performance.

- The study recommends larger board size, although the relationship is not significant. However, the logic is to bring in a large board with the required expertise and knowledge to efficiently run the company.

\section{References}

Agrawal, A. and C. Knoeber. (1996). Firm Performance and Mechanisms to Control Agency Problems Between Managers and Shareholders. Journal of Financial Quantitative Analysis, 31(3), 377-397. http://dx.doi.org/10.2307/2331397

Anderson, R.C. and D.M. Reeb (2008). Founding-Family Ownership and Firm Performance: Evidence from the S\&P 500. The Journal of Finance, LVIII(3), June, 1301-1328.

Aydin, N, Sayim, M, \& Yalama A. (2007). Foreign Ownership and Firm Performance: Evidence from Turkey. International Research Journal of Financial Economics, 11.

Band, R. (1981). The Relationship between Return and Market Value of Common Stocks. Journal of Financial Economics, 9, 3-18. http://dx.doi.org/10.1016/0304-405X(81)90018-0

Baysinger, B. and Heskisson, R.E. (1990). The Composition of Boards of Directors and Strategic Control: Effects on Corporate Strategy. Academy of Management Review, 15(1), 72-87.

Berle, A., and G. Means. (1932). The Modern Corporation and Private Property. The Macmillan Company, New York. 
Bertrand, M., P. Mehta, and S. Mullainathan (2002). Ferreting out Tunnelling: An Application to Indian Business Groups. Quarterly Journal of Economics, 117(1), 121-148. http://dx.doi.org/10.1162/003355302753399463

Bhattacharya S. , Graham, M.(2007). Institutional Ownership and Firm Performance: Evidence from Finland. School Working Paper - Accounting/Finance Series 2007 SWP 2007/01

Blasi, J. and A. Shleifer (1996) Corporate Governance in Russia: An Initial Look, in Frydman, Roman, Cheryl W Gray and Andrzej Rapaczynshil, eds. Corporate Governance in Central Europe and Russia. Volume 2, Insiders and the State, Budapest, Hungary: CEU Press.

Chemin, M(2007). The Impact of the Judiciary on Economic Activity: Evidence from India. Working Paper 07-24

Claessens, S. (1997). Corporate Governance and Equity Prices: Evidence from the Czech and Slovak Republics. Journal of 1641-1658. http://dx.doi.org/10.1111/j.1540-6261.1997.tb01124.x

Claessens, S. and S. Djankov (1999). Ownership Concentration and Corporate Performance in the Czech Republic. Journal of Comparative Economics, 27(3), 498-513. http://dx.doi.org/10.1006/jeec.1999.1598

Claessens, S., Djankov,S., and Pohl, G. (1996). Ownership and Corporate Governance: Evidence from the Czech Republic. The World Bank, Washington, DC. Available at http://econ.worldbank.org/docs/660.pdf

Coles, J. L., Daniel, N. D. and Naveen, L. (2008). Boards: Does one size fit all? Journal of Financial Economics, 87, 329-356. http://dx.doi.org/10.1006/jcec.1999.1598

Cubbin, J. and D. Leech (1983) Ownership structure and economic performance in the largest European companies. Strategic Management Journal, 21(6), 689-705.

Demsetz, H. (1983) The Structure of Ownership and the Theory of the Firm. Journal of Law Economics, 7, 26375-390.

Demsetz, H. and K. Lehn (1985) The Structure of Corporate Ownership: Causes and Consequences. Journal of Political Economy, 93, 1155-77. http://dx.doi.org/10.1086/261354

Demsetz, Harold and Villalonga, Belen,(2001). Ownership Structure and Corporate Performance. Journal of Corporate Finance, 7, 209-233. Available at SSRN: http://ssrn.com/abstract=304181

Gilson, S. (1997). Transaction Costs and Capital Structure Choice: Evidence from Financial Distressed Firms. Journal of 5inance, 161-195. http://dx.doi.org/10.1111/j.1540-6261.1997.tb03812.x

Górriz, C. G. And Fumas, V. S.. 1996. Ownership Structure and Firm Performance: Some Corporate value. Journal of Financial Economics, 27, 595-612. 
http://www.bseindia.com

http://www.competition-commission-india.nic.in

http://www.finmin.nic.in

http://www.icai.org

http://www.irdaindia.org

http://www.mca.gov.in

http://www.rbi.org.in

http://www.sebi.gov.in

Jensen, M. and Meckling, W. (1976) .Theory of the Firm: Managerial Behavior, Agency Costs and Ownership Structure. Journal of Financial Economics, 3, 305-360. http://dx.doi.org/10.1016/0304-405X(76)90026-X

Jensen, M.C. (1989). Eclipse of the Public Corporation. Harvard Business Review, Sept.-Oct., Available at

SSRN: http://ssrn.com/abstract $=146149$ or 10.2139/ssrn.10.2139/ssrn.146149.

Joh, S.W. (2003). Corporate Governance and Firm Profitability: Evidence from Korea before the Economic Crisis. Journal of Financial Economics, 68(2), 287-322. http://dx.doi.org/10.1016/S0304-405X(03)00068-0

Joshi, A and Hanssens, D.M. (2010). The Direct and Indirect Effects of Advertising Spending on Firm Value. Journal of Marketing 74, 20-33. http://dx.doi.org/10.1509/jmkg.74.1.20

Kaur, P. and Gill, S. (2007). The Effects Of Ownership Structure On Corporate Governance And Performance: An Empirical Assessment In India. Research Project, NFCG.

Kumar, J. (2004). Does Ownership Structure Influence Firm Value? Evidence from India, December, Available athttp://www.stmarys.ca/academic/commerce/economic/IAFEP/papers /kumar.pdf.

La Porta R, Lopez-de-Silanes F, Shleifer A, Vishny R. (1999). Corporate Ownership Around the World. Journal of Finance, 54, 471-517. http://dx.doi.org/10.1111/0022-1082.00115

La Porta, R., F. Lopez-de-Silanes and A. Shleifer (1998). Corporate Ownership around the World. Journal of Finance, 54, 842-893.

La Porta, R., F. Lopez-de-Silanes and A. Shleifer (1998). Law and Finance. Journal of Political Economy, 106, 1113-5. http://dx.doi.org/10.1086/250042

La Porta, R., F. Lopez-de-Silanes, A. Shleifer, R. Vishny (2000). Investor Protection and Corporate Governance. Journal of Financial Economics, 58, 3-27. http://dx.doi.org/10.1016/S0304-405X(00)00065-9

La Porta, R., F. Lopez-de-Silanes, A. Shleifer, R. Vishny (2002). Investor Protection and 
Corporate Valuation.

Journal

of

Finance,

57

1147-70. http://dx.doi.org/10.1111/1540-6261.00457

La Porta, R., F. Lopez-de-Silanes, and A. Shleifer (2006). What Works in Securities Laws. Journal of Finance, 61, 1-32. http://dx.doi.org/10.1111/j.1540-6261.2006.00828.x

Lang, L.H.P. and R.M. Stulz (1994). Tobin's q, Corporate Diversification, and Firm Performance. Journal of Political Economy, 1248-1281. http://dx.doi.org/10.1086/261970

Linck, J., Netter, J. and Yang, T. (2008). The Determinants of Board Structure. Journal of Financial Economics, 87, 308-328. http://dx.doi.org/10.1016/j.jfineco.2007.03.004

McConnell J. J. and Servaes, H. (1990). Additional evidence on equity ownership and Money, Credit, and Banking, 1, 15-29.

Milgrom, P. and J. Roberts. (1992). Economics, Management and Organization, Englewood Cliffs, NJ: Prentice Hall.

Ongore, O.V., K'Obonyo O. P., and Ogutu,M. (2011 ). Implications of Firm Ownership Identity and Managerial Discretion on Financial Performance: Empirical Evidence from Nairobi Stock Exchange. International Journal of Humanities and Social Science, 1, 13.

Reinganum, M. (1981). Misspecification of Capital Asset Pricing: Empirical Anomalies based on Earnings' Yields and Market Values. Journal of Financial Economics, 9, 19-46. http://dx.doi.org/10.1016/0304-405X(81)90019-2

Repei, V. (2000). Ownership structure, Corporate Governance, and Corporate Performance: Evidence from Ukraine. M.A. (Economics). Thesis presented to the National University of Kyiv-Mohyla Academy.

Sarkar, Jayati, and Sarkar, S. (2000). Large Shareholder Activism in Corporate Governance in Developing Countries: Evidence From India. International Review of Finance, 1(3), 161-194. http://dx.doi.org/10.1111/1468-2443.00010

Shleifer, Andrei, and Robert W. Vishny(1986). Large Shareholders and Corporate Control. Journal of Political Economics, 94(3), 461-488. http://dx.doi.org/10.1086/261385

Shleifer,A. Vishny W.R.(1997). A Survey of Corporate Governance. The Journal of Finance, 52(2), 737-783. http://dx.doi.org/10.1111/j.1540-6261.1997.tb04820.x

Thomsen, S. and Pedersen, T. (2000). Ownership Structure and Economic Performance in the Largest European Companies. Strategic Management Journal, 21, 689-705. http://dx.doi.org/10.1002/(SICI)1097-0266(200006)21:6<689::AID-SMJ115>3.0.C $\mathrm{O} ; 2-\mathrm{Y}$

Thomsen, S. and T. Pedersen (1998). Industry and Ownership Structure. International Empirical Evidence from Spain. Management and Decision Economics, 17, 575-586.

Tobin, J. (1969). A General Equilibrium Approach to Monetary Theory. Journal of Review of 
Law and Economics, 18(4), 385-402.

Tobin, J. and W. Brainard (1968). Pitfalls in Financial Model Building. American Economic Review, 59, 99-102.

Wiwattanakantang, Y. (1999). An Empirical Study on the Determinants of the Capital Structure of Thai Firms. Pacific-Basin Finance Journal, 7, 371-403. http://dx.doi.org/10.1016/S0927-538X(99)00007-4

$\mathrm{Xu}$, Xiaonian and Wang, Yan,(1997). Ownership Structure, Corporate Governance and Corporate Performance: The case of Chinese Stock Companies. World Bank Policy Research Working Paper No 1794. Available at SSRN: http://ssrn.com/abstract=45303.

Yee, H.S. (1998). A Study on Relationship between Ownership and Return in Malaysia. MBA thesis, University of Malaya, Kuala Lumpur.

Yeh, Y.H., T.S. Lee, and T. Woidtke (2001). Family Control and Corporate Governance: Evidence from Taiwan. International Review of Finance, 2, 21-48. http://dx.doi.org/10.1111/1468-2443.00014

\section{Copyright Disclaimer}

Copyright for this article is retained by the author(s), with first publication rights granted to the journal. 